Research Article

\title{
Olive Cuttings as Affected by Different Concentrations of Indole Butyric Acid
}

\author{
Noor Ayaz ${ }^{1 *}$, Faiza Aman ${ }^{1}$, Sidra Saleem ${ }^{1 *}$, Maqbool Rehman ${ }^{1}$ and Muhammad Fahim ${ }^{2}$
}

${ }^{1}$ Department of Horticulture, The University of Agriculture, Peshawar, Khyber Pakhtunkhwa, Pakistan; ${ }^{2}$ Department of Plant breeding and Genetics, The University of Agriculture, Peshawar, Khyber Pakhtunkhwa, Pakistan.

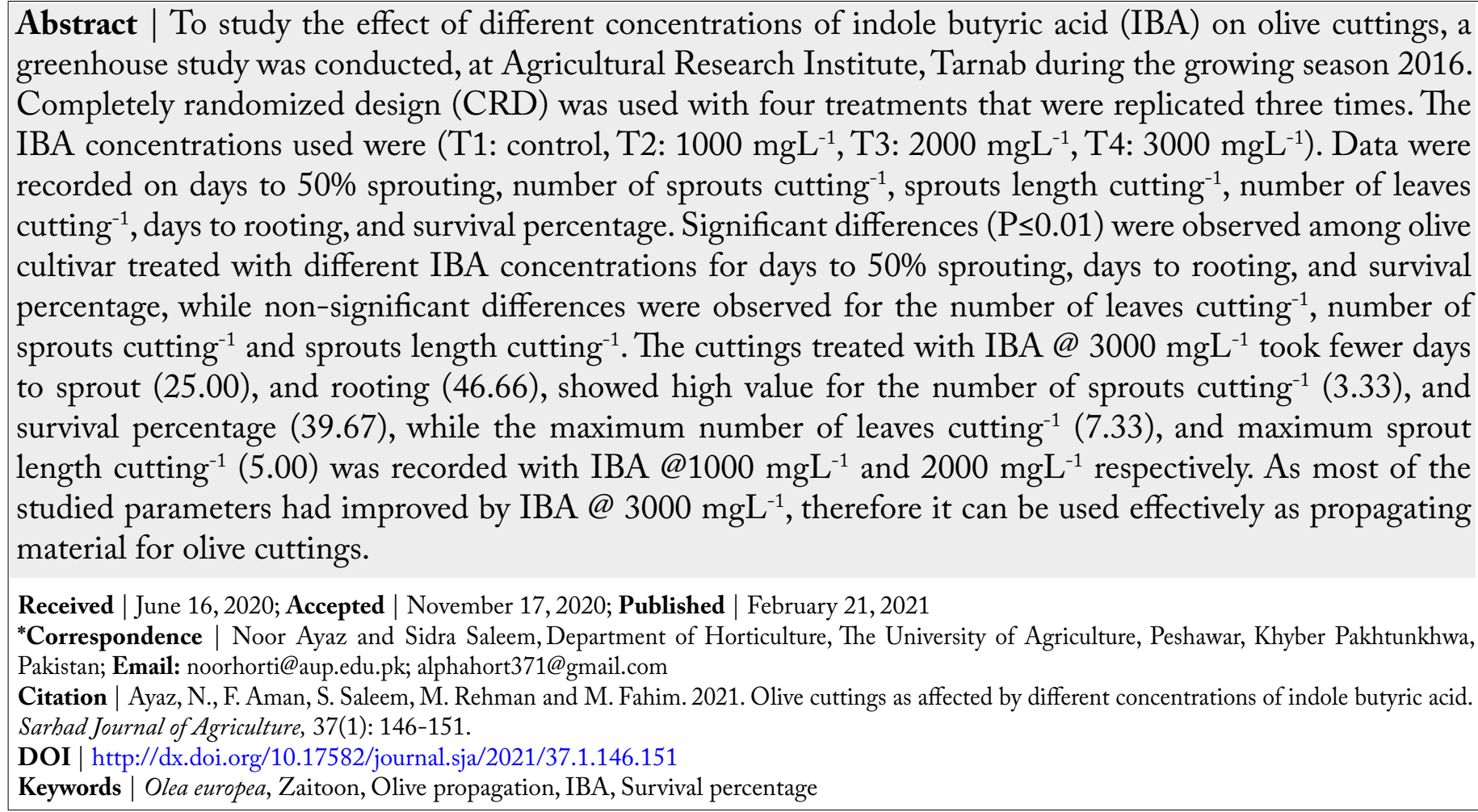

\section{Introduction}

$\mathrm{O}$ live (Olea europea) in Pashto language called Zaitoon or Khuna, is the oldest plant cultivated by man in the world, belongs to the family Oleaceae, used for its fruits and oil production (Brito et al., 2019). Olive has been originated from North West Syria, Palestine, Lebanon and Cyprus (Murkovic et al., 2004). Olive is an evergreen tree with a medium to tall size that can gain up to $15 \mathrm{~m}$. It is a vigorous tree having the ability to promptly regenerate if cut or injured above ground. The olives live for hundreds of years with good production. The trees have dark green, leathery, thick and oppositely arranged leaves (Munir, 2009). The oil of olive is known for its nutritive values and other benefits. It is used in cooking and other preparations such as in massaging creams, pharmaceuticals and cosmetics. Olive oil contains polyunsaturated fatty acids, it is an oil source that is free of cholesterol, and has several health benefits (Awan et al., 2012). In Pakistan olive has not been grown for oil production since the 1970s when its first grooves were established, therefore very negligible research studies have been carried 
out on its cultivation and management. The presence of wild trees of olives in the northern areas of KPK, Balochistan and Potohar region indicates that the climate of these areas is favorable for olive cultivation. Hence, olive cultivation can be successfully initiated in these areas on commercial basis for income generation, and to lowers the country bills on edible oil imports (Breton et al., 2006). Olive can be propagated through different methods; it can be grown from seeds as well as by vegetative methods, but trees grown from seeds take a long time to come into bearing, while asexually propagated trees have genetic uniformity and also come into bearing earlier, than those raised from seeds (Awan et al., 2012). Therefore vegetative methods such as, cutting, grafting, budding or taking rooted suckers from top of the trees etc. can be used for rapid propagation. Among these methods, cutting is most widely used method because of its practicability and simplicity for mass production in a short period of time. Based on the nature of the tissue, there are different types of stem cuttings such as hardwood cuttings, semi-hardwood, softwood and herbaceous (Hartmann et al., 2002; Joshi, 2008). Reduced rooting ability of cuttings is widely attributed to the aging of the mature shoots, and in most cases cuttings taken from mature shoots had lessen ability of rooting (Vidal et al., 2003; Husen and Pal, 2006). Cuttings of various sizes are used which usually ranges from 15 to $25 \mathrm{~cm}$, depending on the cultivar used; these cuttings are then treated with different types of rooting hormones for rapid production of roots (Awan et al., 2012). Under the light of above literature, the present research was intended with the aim to determine the optimum dose of IBA for successful propagation of olive semi hardwood cuttings.

\section{Materials and Methods}

The experiment entitled "Olive cuttings as affected by different concentrations of Indole butyric acid" was conducted at, The Agriculture Research Institute Tarnab, Peshawar Khyber Pakhtunkhwa during 2016. Olive variety (FS-17) was used as a study material. Completely randomized design (CRD) was used with three replications. IBA concentrations used were i.e., T1: control, T2: $1000 \mathrm{mgL}^{-1}$, T3: $2000 \mathrm{mgL}^{-1}, \mathrm{~T} 4: 3000 \mathrm{mgL}^{-1}$. There were a total of 28 cuttings (Semi-hard wood cuttings) in each treatment. The cuttings were planted in polyethylene bags on $30^{\text {th }}$ July, 2016.
Data analysis

The data were analyzed by using statistics software Statistix (ver: 8.1), while for graphical presentation of the main values SigmaPlot (ver: 10.0) were used.

\section{Parameters studied}

Days to $\mathbf{5 0 \%}$ sprouting: Days to $50 \%$ sprouting was counted from the date of sowing to when $50 \%$ cuttings in the treatment initiate sprouting.

Survival percentage (\%): It was calculated by counting the survived plants after transplantation and the percentage was found.

Number of sprouts cutting ${ }^{-1}$ : It was calculated when cuttings were ready for transplantation the number of sprouts per cutting was recorded in each treatment.

Sprouts length cutting ${ }^{-1}(\mathbf{c m})$ : Sprouts length was measured on five randomly selected cuttings in each treatment with the measuring tape and their average was taken.

Number of leaves cutting ${ }^{-1}$ : Number of leaves was counted on five randomly selected cuttings in each treatment and their average was calculated.

Days to rooting: Days to rooting was taken from date of sowing till initiation of roots.

\section{Results and Discussion}

The analysis of variance and mean values of the studied attributes are given in (Table 1) and (Table 2) respectively, while Figure 1 shows the graphics of the mean data.

Table 1: Analysis of variance for various traits of olive variety.

$\begin{array}{lll}\text { Traits } & \text { Mean squares } & \text { Error MS } \\ \text { Days to 50\% sprouting } & 58.7778^{* *} & 1.4167 \\ \text { Number of sprouts cutting-1 }^{-1} & 2.30556^{\mathrm{NS}} & 0.91667 \\ \text { Sprout length cutting }^{-1} & 0.75000^{\mathrm{NS}} & 3.08333 \\ \text { Number of leaves cutting- }^{-1} & 2.30556^{\mathrm{NS}} & 3.25000 \\ \text { Days to rooting } & 174.750^{* *} & 0.583 \\ \text { Survival percentage } & 47.2222^{* *} & 0.5000 \\ \text { * **: significant at 1\% and 5\% level of probability respectively; NS: } \\ \text { non-significant. }\end{array}$

March 2021 | Volume 37 | Issue 1 | Page 147 
Table 2: Mean values for various traits of olive cuttings.

$\begin{array}{lllllll}\text { Treatments } & \begin{array}{l}\text { Days to 50\% } \\ \text { sprouting }\end{array} & \begin{array}{l}\text { No. sprouts } \\ \text { cutting }^{-1}\end{array} & \begin{array}{l}\text { Sprout length cut- } \\ \text { ting }^{-1} \mathbf{( c m )}\end{array} & \begin{array}{l}\text { No.leaves } \\ \text { cutting }^{-1}\end{array} & \begin{array}{l}\text { Days to } \\ \text { rooting }\end{array} & \begin{array}{l}\text { Survival percent- } \\ \text { age (\%) }\end{array} \\ \text { Control } & 35.33 \mathrm{~A} & 1.66 & 5.00 & 7.00 & 63.66 \mathrm{~A} & 30.33 \mathrm{D} \\ 1000 \mathrm{mgL}^{-1} & 27.33 \mathrm{~B} & 2.00 & 4.33 & 7.33 & 61.33 \mathrm{~B} & 34.00 \mathrm{C} \\ 2000 \mathrm{mgL}^{-1} & 29.00 \mathrm{~B} & 3.00 & 5.00 & 6.66 & 54.66 \mathrm{C} & 36.67 \mathrm{~B} \\ 3000 \mathrm{mgL}^{-1} & 25.00 \mathrm{C} & 3.33 & 4.00 & 5.33 & 46.66 \mathrm{D} & 39.67 \mathrm{~A}\end{array}$

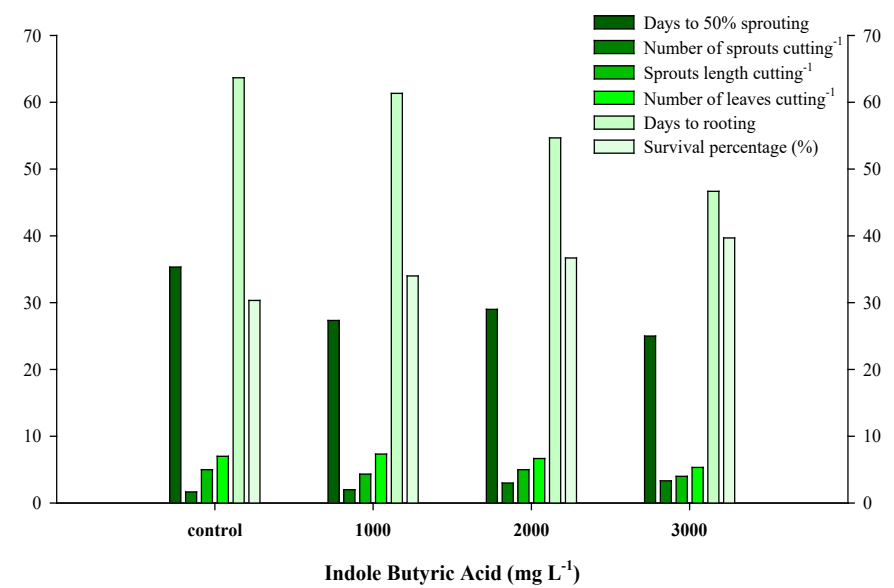

Figure 1: The Effect of different IBA concentrations on olive cuttings.

\section{Days to $50 \%$ sprouting}

Significant differences $(\mathrm{P} \leq 0.01)$ were observed among olive variety for days to $50 \%$ sprouting. Less number of days to $50 \%$ sprouting $(25.00)$ were noted at $3000 \mathrm{mgL}^{-1} \mathrm{IBA}$ concentration, while maximum days (35.33) were recorded at control.

\section{Number of sprouts cutting ${ }^{-1}$}

Non-significant differences were observed for the number of sprouts cutting ${ }^{-1}$. Minimum number of sprouts cutting $^{-1}$ (1.66) was recorded at control, while maximum number of sprouts (3.33) cutting $^{-1}$ was recorded at $3000 \mathrm{mgL}^{-1} \mathrm{IBA}$ concentration.

\section{Sprouts length cutting ${ }^{-1}(\mathrm{~cm})$}

Non-significant differences were observed for sprouts length cutting ${ }^{-1}$. Minimum sprout length cutting $^{-1}(4.00 \mathrm{~cm})$ was recorded at $3000 \mathrm{mgL}^{-1} \mathrm{IBA}^{-}$ concentration, while maximum sprout length (5.00 $\mathrm{cm}$ ) was recorded at control and $2000 \mathrm{mgL}^{-1}$ IBA concentration.

\section{Number of leaves cutting ${ }^{-1}$}

Non-significant differences were recorded for number of leaves cutting ${ }^{-1}$. Minimum number of leaves cutting $^{-1}$ (5.33) were recorded at $3000 \mathrm{mgL}^{-1}$ IBA concentration, while maximum leaves (7.33) cutting $^{-1}$ were recorded at $1000 \mathrm{mgL}^{-1}$ IBA concentration.

\section{Days to rooting}

Significant differences $(\mathrm{P} \leq 0.01)$ were noticed among different treatments for number of days to rooting. Minimum days to rooting (46.66) were recorded at IBA $3000 \mathrm{mgL}^{-1}$, while maximum value (63.66) was recorded for the control.

\section{Survival percentage (\%)}

Significant variations $(\mathrm{P} \leq 0.01)$ were found among various treatments for survival percentage. Minimum value (30.33) of survival percentage was recorded at control, while maximum value (39.67) was recorded at $3000 \mathrm{mgL}^{-1} \mathrm{IBA}$ concentration.

In contrast to our results, a non-significant effect of IBA was found on the number of days to bud sprout; this can be due to the indirect effect of IBA on shoot development as these hormones are mostly responsible for root induction. In line with these results Wahab et al. (2001) also reported a non-significant effect of IBA on days to bud sprout. Sprouting of buds could be due to the presence of stored carbohydrates in the cuttings. Ibadullah et al. (2015) stated that IBA concentrations did not affect the number of shoots cutting ${ }^{-1}$, a nonsignificant effect of IBA was also found by Siddique and Hussain (2007) in Ficus Hawaii. The total number of shoots produced per cutting could be attributed to the equal length of cutting above ground which had an equal number of nodes. Concerning shoot length a significant effect was observed at IBA 300 ppm with the highest shoot length of $(21.5 \mathrm{~cm})$, while the minimum value $(4.9 \mathrm{~cm})$ was recorded at control. In line with these results Naghmouchi et al. (2008) stated that IBA a growth promoter improves cell division, which leads to early rooting and subsequently improves nutrients absorption that results an increasing shoot length. Hussein et al. (2017) reported that IBA treatments significantly influenced the number of leaves cutting ${ }^{-1}$ and shoot length; the highest number of leaves cutting ${ }^{-1}(14.40)$, and maximum shoot length $(4.94 \mathrm{~cm})$ was recorded with IBA @ $4000 \mathrm{mgL}^{-1}$. The improved shoot length and number of leaves can be 
attributed to the auxins basic functions in cell division and cell elongation. IBA different concentrations influenced various rooting parameters of olive stem cutting (Khajehpour et al., 2014). There were significant differences among the treatments, at 3000 $\mathrm{mgL}^{-1}$ the highest rooting percentage $(60 \%)$ were recorded, while at $4000 \mathrm{mgL}^{-1}$ other parameters such as the average root number per cutting, and average root length was noted. The significant effect of IBA can be attributed to the hormonal balance in the cuttings which influenced the root formation (Kurd et al., 2010). John (2004) reported that root formation can be initiated at any injured or damaged stem end by the application of rooting compounds. The healing process will occur naturally in the cuttings and roots will grow, the delaying caused by the transport of auxins from top to the cut stem can be avoided through the treatment of a small but significant amount of synthetic rooting compound. IBA an auxin usually used for the formation and regeneration of roots in plants. Auxins have differential root-generating capacities, which may depend on their respective role in the synthesis of proteins needed for roots formation (Saini et al., 2013). The overall promotive influence of auxins on rooting of plants is the stimulation of cell division in the vascular cambium which ultimately results in the formation of root primordia (Rahman et al., 2002). Isfendiyaroglu and Ozeker (2008) also found a positive effect of IBA treatments on all rooting characters in an olive variety "Domat". Bayraktar et al. (2018) recorded the highest rooting percentage (70\%) at 5000 ppm IBA and 5000 ppm NAA, while studying the effect of different auxins on the propagation of olive species (Elaeagnus umbellata) through cuttings, the longest root length, the highest root number, and first root formation was recorded with IBA $5000 \mathrm{ppm}$ at the $20^{\text {th }}$ day of the treatment. Bayraktar (2017) studied the influence of IBA (1000 ppm, 5000 ppm) along with different greenhouse media on softwood cuttings of olive same species, and among these treatments, 100\% rooting percentage was recorded with IBA @ 1000 ppm. Ibadullah et al. (2015) noted that IBA significantly improved the survival percentage of different types of olive cuttings. The highest survival percentage was recorded at $300 \mathrm{ppm}$ followed by a concentration of $200 \mathrm{ppm}$, whereas the lowest survival was recorded at control. These results are supported by Sukhjit (2017) who stated that the high survival rate might be due to the direct effect of IBA on growth regulators which stimulates the formation of adventitious roots, these in turn absorbs nutrients from the soil and help survives the plants. A similar effect of IBA on lateral root development in rice was also found by Wang et al. (2003).

\section{Conclusions and Recommendations}

The research work was carried out under a project headed by the Agricultural Research Institute Tarnab, Peshawar which aimed for the uplift of the oil industry through the integration and development of new and high yielding olive varieties and upgrading of existing olive orchards across the province. The current study that was designed to examine the effect of IBA concentrations on olive cuttings, revealed significant effects of the treatments on days to $50 \%$ sprouting, days to rooting and survival percentage while showed non-significant differences for number of leaves cutting ${ }^{-1}$, number of sprouts cutting ${ }^{-1}$ and sprout length cuttings ${ }^{-1}$. Among different levels of IBA (1000 mg L-1, $2000 \mathrm{mg} \mathrm{L}^{-1}$, and $3000 \mathrm{mg} \mathrm{L}^{-1}$ ), IBA @ $3000 \mathrm{mg} \mathrm{L}^{-1}$ proved to be more effective for the studied attributes. Hence, it is recommended to be used as propagating material for olive cuttings.

\section{Acknowledgments}

All authors are highly thankful to the Agricultural Research Institute Tarnab, Peshawar for provision of study materials and administering during the whole course of experiment.

\section{Novelty Statement}

As most of the olive cultivars are hard to root therefore for successful rooting of the olives different types of growth hormones are used. Indole butyric acid is an auxin mostly used for the same purpose. The present study also assesses the best IBA levels for olive propagation, which showed significant effects on the studied parameters, hence the treatment levels used in this study can be used for successful propagation of olive cuttings.

\section{Author's Contribution}

Faiza Aman supervised and designed the experiment. Noor Ayaz performed the experiment and analyzed the data and Sidra Saleem wrote the first draft of the manuscript. All authors read and approved the final manuscript. 
Conflict of interest

The authors have declared no conflict of interest.

\section{References}

Awan, A., A.E. Ullah, S.J. Abbas, O. Khan and S. Masroor. 2012. Growth response of various olive cultivars to different cutting lengths. Pak. J. Agric. Sci., 49(3): 315-318.

Bayraktar, A., 2017. Bazı süs bitkisi türlerinin çelik ile köklendirilmesinde farklı ortam ve hormon etkilerinin araştırılması, Yüksek Lisans Tezi, Karadeniz Teknik Üniversitesi, Fen Bilimleri Enstitüsü, Trabzon.

Bayraktar, A., N. Yildirim, F. Atar and I. Turna. 2018. Effects of some auxins on propagation by hardwood cutting of Autumn Olive (Elaeagnus umbellata Thunb). Turk. J. For. Res., 5(2): 112116.

Breton, C., F. Medail, C. Pinatel and A. Berville, 2006. From olive tree to Oleaster: Origin and domestication of Olea europaea L. in the Mediterranean basin. Cahiers Agric., 15(4): 329-336.

Brito, C., T.D. Lia, M.P. Jose and M.C. Carlose. 2019. Drought stress effects and olive tree acclimation under a changing climate. Plants (Basel), 8(7): 232. https://doi.org/10.3390/ plants 8070232

Hartmann, H.T., D.E. Kester, F.T. Davies and R.L. Geneve, 2002. Plant propagation: Principles and practice, $7^{\text {th }}$ edn. Prentice Hall, Upper Saddle River, New Jersey.

Husen, A. and M. Pal. 2006. Variation in shoot anatomy and rooting behaviour of stem cutting in relation to age of donor plants in teak (Tectona grandis Linn. F). New Forests. 31: 5773. https://doi.org/10.1007/s11056-004-67945

Hussein, B.A., Y.A.R. Goran and M.Q. Khurshid. 2017. Effect of different concentrations of IBA on rooting ability and shooting in olive (Olea europea L. cv. Dgel) cuttings. Int. Conf. Works. Basic Appl. Sci. Erbil-KRG-IRAQ.

Ibadullah, J., S. Muhammad, R. Abdur, I. Amjad, K. Owais, J. Yousaf, A. Naveed, A. Asad, S. Muhammad and T.S. Syed. 2015. Effect of various concentrations of Indole butyric acid (IBA) on olive cuttings. Mitt Eilungen Klosterneuburg, 65: 49-55.

Isfendiyaroglu, M. and O. Elmas. 2008. Rooting of Olea europea 'domat' cuttings by auxin and salicylic acid treatments. Pak. J. Bot. 40(3): 1135-1141.

John, R.H., 2004. The basics of plant growth; (Part 3) root formation in cuttings. Article source. http://ezinearticles.com/expert=John_R._ Haughton.

Joshi, P., 2008. Eco physiology of olive cultivars (Olea europea Linn. cv. Pendolino and Olea ferruginea Royle) grown in Almora hills, Kumaun Himalaya, Uttarakhand. M.Sc. thesis, Kumaun University, Almora, India.

Khajehpour, G., V. Eizadeh and N. Khajehpour. 2014. Effect of Different concentration of IBA (Indole butyric Acid) hormone and cutting season on the rooting of the cuttings of olive (Olea europea Var. Manzanilla). Int. J. Adv. Biol. Biom. Res., 2(12): 2920-2924.

Kurd, A.A., A.S. Khan, B.H. Shah and M.A. Khetran. 2010. Effect of indole butyric acid on rooting of olive stem cuttings. Pakistan J. Agric. Res., 23: 3-4.

Munir, B.L., 2009. Various propagation approaches in olive. B.Sc. (Hons) internship report KP. Agric. Univ. Pesh. Pakistan, pp. 22-23.

Murkovic, M., S. Lechner, A. Pietzka, M. Bratacos and E. Katzogiannos. 2004. Analysis of minor components in olive oil. J. Biochem. Methods. 61: 155-160. https://doi.org/10.1016/j. jbbm.2004.04.002

Naghmouchi, S., M.L. Khouja, M.N. Rejeb and M. Boussaid. 2008. Effect of growth regulators and explant origin on in vitro propagation of (Ceratonia siliqua L.) via cuttings. Biotechnol. Agron. Soc. Environ., 12(3): 251-258.

Rahman, N., A. Azmat, N. Ghumlam and A. Zafar. 2002. Root initiation in hard wood cutting of olive cultivar Corantina using different concentrations of IBA. Asian J. Plant Sci., 5: 563-564. https://doi.org/10.3923/ ajps.2002.563.564

Shivani, S., I. Sharma, N. Kaur and P.K. Pati. 2013. Auxin: A master regulator in plant root development. Plant Cell Rep., 32:741-757.

Siddiqui, M.I. and S.A. Hussain. 2007. Effect of indole butyric acid and types of cuttings on root initiation of Ficus hawaii. Sarhad J. Agric., 23(4): 919-925.

Sukhjit, K., 2017. Evaluation of different doses of indole-3-butyric acid on the rooting, survival and vegetative growth performance of hardwood 
cuttings of Flordaguard peach (Prunus persica L.). J. Appl. Natl. Sci., 9(1): 173-180. https:// doi.org/10.31018/jans.v9i1.1167

Vidal, N., G. Arellano, M.C. San-Jose, A.M. Vieitez and A. Ballester. 2003. Developmental stages during the rooting of in vitro-cultured (Quercus robur) shoots from material of juvenile and mature origin. Tree Physiol.,23:1247-1254. https://doi.org/10.1093/treephys/23.18.1247

Wahab, F., G. Nabi, A.M. Nawab and M. Shah.
2001. Rooting response of semi-hardwood cuttings of guava (Psidium guajava L.) to various concentrations of different auxins. Online J. Biol. Sci., 1: 184-187. https://doi.org/10.3923/ jbs.2001.184.187

Wang, S., S. Taketa, M. Ichii, L. Xu, K. Xia and X. Zhou. 2003. Lateral root formation in rice (Oryza sativa L.) differential effects of indole3-acetic acid and indole-3-butyric acid. Plant growth regulation. 41: 41-47. 